\title{
ANALISIS NETWORK DAN GEOMETRI PADA SISTEM GRANULAR DUA DIMENSI
}

\author{
Widya Meiriska, a), Sparisoma Viridi ${ }^{1, \text { b) }}$, Dimas P. P. A ${ }^{2, c)}$, Putri Mustika W., ${ }^{1, d)}$ \\ ${ }^{1}$ Program Studi Fisika \\ ${ }^{2}$ Program Studi Sains Komputasi \\ Fakultas Matematika dan Ilmu Pengetahuan Alam, Institut Teknologi Bandung, \\ Jl. Ganesha no. 10 Bandung, Indonesia, 40132 \\ Email: ${ }^{a)}$ widya.meiriska@gmail.com, ${ }^{b)}$ dudung@fi.itb.ac.id, ${ }^{c}$ dmspraja2105@gmail.com, \\ d)putrimw.itb@gmail.com
}

\begin{abstract}
Abstrak
Pengaturan partikel dan gaya dalam material granular dan materi partikulat memiliki organisasi yang kompleks pada skala spasial. Organisasi seperti ini dapat mempengaruhi bagaimana material merespon atau mengkonfigurasi ulang ketika terkena gangguan atau pemuatan eksternal. Studi teoritis sifat-sifat partikel, force-chain dan domain memerlukan pengembangan dan penerapan kerangka kerja matematis, stastistik, fisika dan komputasi yang tepat. Secara tradisional bahan granular telah diselidiki menggunakan partikel atau model rangkaian yang masing-masing cederung secara implisit. Dewasa ini pengembangan ilmu jaringan (network science) telah muncul sebagai pendekatan yang kuat untuk menyelidiki dan mencirikan arsitektur heterogen dalam sistem yang kompleks dan beragam metode telah menghasilkan wawasan yang menarik kedalam material granular. Dalam studi ini akan meninjau pendekatan berbasis jaringan untuk mempelajari material granular dan mengeksplorasi potensi kerangka tersebut untuk memberikan deskripsi yang berguna dari material granular ini. Serta untuk meningkatkan pemahaman tentang fisis yang mendasarinya. Penelitian dilakukan dengan melakukan simulasi menggunakan program python 3.6. Dari hasil simulasi dan dilakukan analisis network pada material granular (perkembangbiakan koloni ragi) dapat disimpulkan pendekatan berbasis network ini mampu memberikan informasi yang tidak dapat diketahui sebelumnya, bahwa perkembangbiakan koloni ragi tidak dipengaruhi oleh umur dan diameter sel, serta kecenderungan sel anak yang sering berada pada jarak yang cukup dekat dengan sel induk.
\end{abstract}

Kata-kata kunci: Analisis network, jaringan, sistem granular

\begin{abstract}
The arrangement of particles and forces in granular materials and particulate matter has complex organizations on a spatial scale. Such organizations may affect how materials respond or reconfigure when exposed to external interference or loading. Theoretical studies of particle, force-chain and domain properties require the development and application of appropriate mathematical, statistical, physical and computational frameworks. Traditionally granular materials have been investigated using particles or circuit models that are each implicitly. Today the development of network science has emerged as a powerful approach to investigate and characterize heterogeneous architecture in complex systems, and diverse methods have yielded interesting insights into granular materials. In this study will review the network-based approach to study granular materials and explore the potential of these frames to provide a useful description of these granular materials. As well as to improve understanding of the underlying physics. The study was conducted by simulating using python 3.6 programs. From the simulation results and carried out network analysis on granular material (breeding of yeast colonies) it
\end{abstract}


can be concluded that this network-based approach can provide information that cannot be known previously, that the breeding of yeast colonies is not influenced by the age and tendency of child cells that are often at a close distance. With parent cells.

Keywords: Complex system, Granular, Network Analysis.

\section{PENDAHULUAN}

Para ilmuwan dan insinyur telah lama menggunakan model matematis dan komputasional untuk analisis dan desain sistem berbasis fisika, seperti dalam menggambarkan evolusi cuaca dan iklim, perilaku proses fisik kompleks dalam perangkat pembakaran, desain bahan, sistem persenjataan dan produksi energi. Model-model ini sering dapat digambarkan oleh sistem persamaan diferensial parsial. Dewasa ini metodologi canggih yang dikenal dengan pendekatan berbasis jaringan (network) telah dikembangkan untuk menerjemahkan fisika ke dalam model matematika dan komputasi yang dapat dianalisis dan dipahami untuk memberikan pemahaman prediktif tentang perilaku mereka. Ternyata banyak sistem yang rumit mampu dijelaskan dengan pendekatan berbasis network ini. Perkembangan ilmu jaringan (network science) telah muncul sebagai pendekatan yang kuat untuk menyelidiki dan mencirikan arsitektur heterogen dalam sistem yang kompleks.

Analisis jaringan (network) adalah suatu bentuk analisis data matematis yang mengungkap sifat, tingkat dan struktur hubungan individu di antara berbagai hal. Individu tersebut bisa dari keluarga organisme, bagi para ahli biologi; subkelompok antar manusia, dulu dan sekarang, bagi antropolog, hubungan sebab dan akibat yang dihipotesiskan, untuk analisis sistem dinamis yang kompleks dan seterusnya, atau dapat berupa orang dan organisasi untuk sosiolog, sejarawan dan ekonom. Penggunaan metodologi yang paling terkenal adalah dalam "analisis jejaring sosial", yang melibatkan koneksi orang-orang di komunitas seperti LinkedIn dan Facebook.

Pada studi ini akan dicoba diterapkan pendekatan berbasis jaringan (network) untuk menganalisis sistem granular dua dimensi. Sistem granular yang ditinjau yaitu perkembangbiakan koloni ragi yang telah disimulasikan menggunakan javascript.

\section{TEORI GRAPH}

Dalam ilmu matematika, network atau jaringan dikenal sebagai graph. Dalam teori graph titik disini dikenal dengan istilah simpul (node) yang merepresentasikan objek, serta sisi (edge) yang merepresentasikan penghubung antara satu node dengan node lainnya. Maka secara informal, suatu graph adalah himpunan benda-benda yang disebut simpul (vertex atau node) yang terhubung oleh sisi (edge) atau busur ( $a r c)$. Graph digunakan untuk merepresentasikan objek-objek diskrit dan hubungan antara objek-objek tersebut[2].

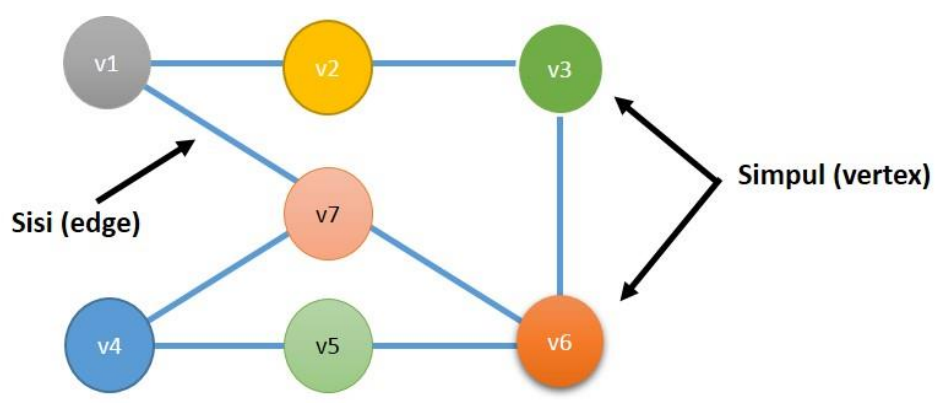

GAMBAR 1. Interpretasi node (simpul) dan edge (simpul).

Suatu graph $\mathrm{G}$ dapat dinyatakan sebagai $G=(V ; E)$. Graph $\mathrm{G}$ terdiri atas himpunan V yang berisikan simpul dan himpunan dari E yang berisi sisi pada graph tersebut. Himpunan E dinyatakan sebagai pasangan dari simpul yang ada dalam V. Banyak sekali struktur yang bisa direpresentasikan dengan graph, dan banyak masalah yang bisa diselesaikan dengan bantuan graph. Jaringan 
persahabatan pada facebook bisa direpresentasikan dengan graph, yakni simpul-simpulnya adalah para pengguna facebook dan ada sisi antar pengguna jika dan hanya jika mereka berteman. Perkembangan algoritma untuk menangani graph akan berdampak besar bagi ilmu komputer. Sebuah struktur graph bisa dikembangkan dengan memberi bobot pada tiap sisi. Graph berbobot dapat digunakan untuk melambangkan banyak konsep berbeda. Sebagai contoh jika suatu graph melambangkan jaringan jalan maka bobotnya bisa berarti panjang jalan maupun batas kecepatan tertinggi pada jalan tertentu. Ekstensi lain pada graph adalah dengan membuat sisinya berarah, yang secara teknis disebut graph berarah atau (directed graph). Directed graph dengan sisi berbobot disebut jaringan. Jaringan banyak digunakan pada cabang praktis teori graph yaitu analisis jaringan. Perlu dicatat bahwa pada analisis jaringan, definisi kata "jaringan" bisa berbeda, dan sering berarti graph sederhana (tanpa bobot dan arah).
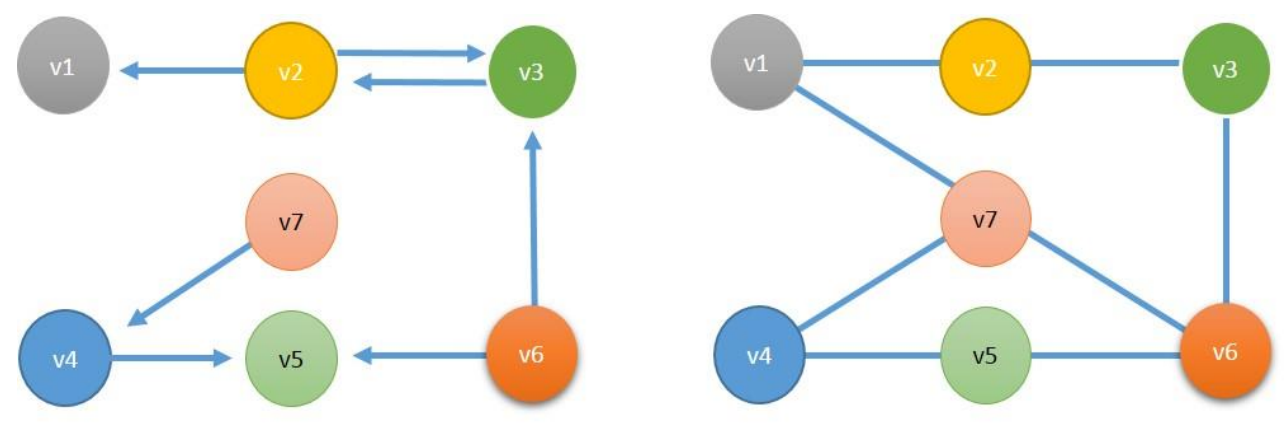

GAMBAR 2. (a) Directed Graph dan (b) Undirected Graph

Selain menggunakan himpunan, jaringan dapat juga direpresentasikan dalam bentuk matriks agar mempermudah seseorang untuk menganalis suatu graph apabila memang diperlukan perhitungan dalam proses analisanya. Interpretasi dalam bentuk matriks ini dikenal dengan matriks ketetanggaan (adjacency matrix). Dalam jaringan tak berarah, suatu sisi $E$ menghasilkan relasi biner yang bersifat simetrik terhadap simpul V yang kemudian disebut sebagai adjacency relation. Hal ini mendasari munculnya adjacency matrix $A_{i j}$. Apabila setiap simpul diberi label maka dapat ditunjukkan sisi sebagai pasangan $(i, j)$, sehingga dapat direspresntasikan dengan menggunakan adjacency matrix (matriks ketetanggaan) yang dapat dituliskan dengan elemen $A_{i j}$. Matriks ketetanggaan merupakan representasi graph yang paling umum digunakan. Matriks ini hanya berisi 0 dan 1, maka matriks ketetanggaan ini dinamakan juga matriks nol satu (zero-one). Selain angka 0 dan 1, elemen matrik dapat juga dinyatakan dengan nilai false (menyatakan 0) dan true (menyatakan 1)[3]. Matriks ketetanggaan didasarkan pada pengurutan nomor simpul. Matriks ketetanggan dapat dituliskan sebagai berikut:

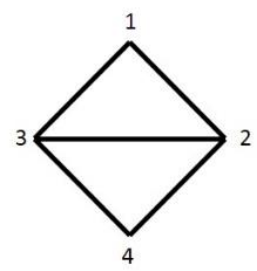

$$
A=\left(\begin{array}{llll}
0 & 1 & 1 & 0 \\
1 & 0 & 1 & 1 \\
1 & 1 & 0 & 1 \\
0 & 1 & 1 & 0
\end{array}\right)
$$

$$
A_{i j}= \begin{cases}1 & \text { jika terdapat edge diantara nodes } i \text { dan } j \\ 0 & \text { lainnya }\end{cases}
$$

GAMBAR 3. Interpretasi jaringan dalam bentuk matrik ketetanggaan (adjacency matrix)

Matriks ketetanggaan untuk graph sederhana dan tidak berarah selalu simetri, sedangkan untuk graph berarah matriks ketetanggaan belum tentu simetri (akan simentri jika berupa graph berarah lengkap). Selain itu diagonal utama selalu nol karena tidak ada sisi gelang (self edge). Pada contoh graph sederhana seperti di atas nilai diagonal dari adjacency matrix nya akan selalu bernilai 0 (nol). 
Terdapat banyak parameter yang berhubungan dengan sebuah graph. Dengan mengetahui nilainilai parameter tersebut dapat memberikan informasi mengenai graph. Berikut parameter yang digunakan pada studi ini.

\section{Derajat (Degree) Simpul dan Distribusi Derajat (Degree Distribution)}

Derajat $k_{i}$ dari simpul i adalah jumlah sisi yang berhubungan dengan simpul dan didefinisikan dengan matriks adjacency A sebagai:

$$
k_{i}=\sum_{j \in v} A_{i j}
$$

Dan jumlah K sisi dari jaringan dapat dihitung dari hubungan

$$
K=\sum_{i \in v} k_{i}
$$

Pada jaringan berarah, derajat simpul terbagi menjadi dua komponen yaitu jumlah sisi yang keluar $k_{i}^{\text {out }}$ (derajat keluar) dan jumlah sisi yang masuk $k_{i}^{\text {in }}$ (derajat masuk).

$$
\begin{aligned}
& k_{i}^{o u t}=\sum_{j} A_{i j} \\
& k_{i}^{i n}=\sum_{j} A_{j i}
\end{aligned}
$$

Total derajat didefinisikan sebagai $k_{i}=k_{i}^{\text {out }}+k_{i}^{\text {in }}$. Sedangkan pada jaringan berbobot, derajat dianalogikan sebagai kekuatan (strength) yaitu jumlah bobot pada sisi-sisi yang berhubungan dengan setiap simpul.

Karakterisasi yang paling dasar dalam suatu graph dapat diperoleh melalui distribusi derajat $P(k)$, yaitu probabilitas untuk menemukan suatu simpul yang memiliki derajat $k$ pada jaringan atau fraksi dari simpul jaringan yang memiliki derajat $\mathrm{k}$. Dalam sudut pandang lain, distribusi derajat dapat dinotasikan sebagai $P(k)$, untuk mengindikasikan asumsi variabel $k$ yang bernilai integer tak negatif. Dalam kasus jaringan berarah, distribusi derajat terbagi menjadi dua komponen yaitu $P\left(k_{i n}\right)$ dan $P\left(k_{\text {out }}\right)$. Informasi mengenai distribusi derajat secara keseluruhan selain dengan melihat grafik $P(k)$ juga dapat dilihat dengan perhitungan momen distribusi. Untuk n momen dari $P(k)$ didefinisikan sebagai:

$$
\left\langle k^{n}\right\rangle=\sum_{k} k^{n} \times P(k)
$$

Momen pertama $\left\langle k^{n}\right\rangle$ menunjukkan derajat rata-rata dari G. Sedangkan momen kedua menghitung fluktuasi dari distribusi derajat. Pada parameter derajat ini juga dikenal adanya istilah degree centrality yang merupakan konsep dari berapa banyak koneksi langsung kepada setiap individu yang ada di cluster[4]. Jadi degree centrality menunjukkan node yang memiliki peran penting dalam suatu cluster berdasarkan banyaknya relasi yang dia milliki dengan node-node lainnya.

$$
C_{D}(i)=\frac{d(i)}{n-1}
$$

Degree centrality ini yang menjadi parameter penting dalam menganalisis sistem granular pada studi ini. 


\section{METODOLOGI PENELITIAN}

Sistem granular merupakan sistem banyak partikel klasik yang bersifat disipatif yang berinteraksi umumnya melalui gaya normal dan juga gaya gesek[1]. Pada studi ini dikaji interaksi antar partikel pada perkembangbiakan koloni ragi yang telah disimulasikan sebelumnya menggunakan javascript. Berikut gambaran simulasi yang telah dilakukan:

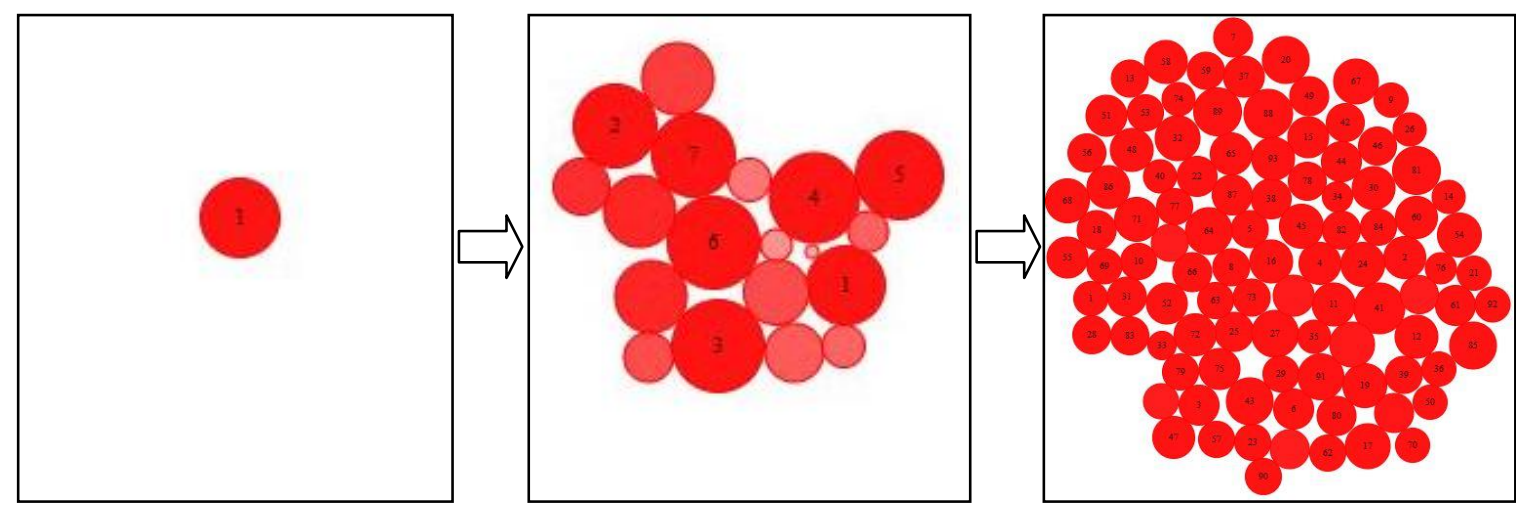

GAMBAR 4. Simulasi perkembangbiakan koloni ragi

Pada gambar di atas terlihat bahwa koloni ragi diinterpretasikan sebagai kumpulan sel-sel yang berbentuk lingkaran, yang kemudian akan terus membelah secara aseksual sampai pada jumlah sel ragi yang diinginkan. Pada studi ini dibatasi perkembangbiakan sel ragi hingga mencapai 100 sel. Apabila telah mencapai 100 sel ragi maka simulasi akan terhenti, dan dilanjutkan ke simulasi berikutnya hingga simulasi ke-100 Perkembangbiakan sel ragi ini diatur secara acak. Dapat dilihat pula bahwa ukuran dari sel ragi di atas juga berbeda-beda. Nomor pada setiap lingkaran menyatakan urutan sel ragi terbentuk, mulai dari yang pertama kali terbentuk hingga sel ragi ke-100.

Pendekatan berbasis jaringan (network) dapat digunakan pada sistem granular ini untuk mengidentifikasi interaksi antara sel ragi. Menemukan koloni yang paling produktif serta mengidentifikasi pengaruh dari produktivitas sel ragi tersebut. Pada jaringan, koloni ragi yang berbentuk lingkaran tersebut merupakan sebuah simpul (node) serta garis keturunan merupakan sisi (edge) yang menghubungan setiap koloni ragi.

Teknik pengkodean dilakukan guna merepresentasikan sel ragi kedalam bentuk representasi jaringan. Teknik pengkodean yang digunakan yaitu matriks biner. Matriks biner berguna karena dapat merepresentasikan ada atau tidaknya hubungan antara masing-masing koloni ragi, sehingga dapat digunakan untuk pembuatan struktur sistem. Pada studi ini, jenis jaringan yang digunakan adala jaringan yang memiliki arah (directed graph) dan memiliki self loops (berhubungan dengan simpul itu sendiri). Self loops dapat diartikan sebagai kondisi awal dari sel ragi yang hanya berjumlah satu, kemudian sel ini membelah diri untuk menghasilkan keturunan selanjutnya. Selain itu pada studi ini juga menggunakan bobot (weight) dengan mengasumsikan setiap hubungan memiliki bobot yang setara dengan jarak antara sel induk dan sel anak. Pengkodean dilakukan dengan menjabarkan data hubungan setiap simpul dan merubahnya menjadi data biner (bernilai antara 0 atau 1) dengan ketentuan apabila terdapat hubungan (satu garis keturunan) antara satu sel dengan sel lain maka akan bernilai 1, dan akan bernilai 0 jika suatu sel tidak saling terkait (tidak satu garis keturunan). Teknik pengkodean ini juga digunakan untuk menghitung derajat (degree) yaitu jumlah sel ragi yang saling berhubungan. Setelah dilakukan teknik pengkodean maka dapat dilakukan perhitungan parameter network dan visualisasinya menggunakan bahasa pemograman Python 3.6. Akan diselidiki pengaruh jarak antara sel induk dengan sel anak dari sel ragi ini. Apakah terdapat pola khusus yang dapat menjelaskan keterkaitan sel induk dengan sel anak.

Berikut alur dari metode penelitian yang dilakukan:

1. Pilih data yang akan diamati dari data mentah yang telah ada 
2. Modifikasi data yang telah dipilih agar mampu diolah menggunakan library dari piranti lunak python 3.6

3. Menentukan parameter yang akan dijadikasi sebagai node (simpul) dan edge (sisi), dalam penelitian ini akan dilihat hubungan anak sel ragi (A) dengan induk sel (I)

4. Melakukan teknik pengkodean pada simpul yang telah dipilih

5. Menghitung parameter-parameter network yang ingin diketahui

6. Visualisasi data

7. Selesai

\section{HASIL DAN PEMBAHASAN}

Dengan memanfaatkan beberapa data simulasi dari 100 data simulasi, telah berhasil dilakukan perhitungan serta pemetaan struktur dari koloni ragi. Berikut hasil pemetaan struktur koloni ragi pada simulasi pertama

TABEL 1. Hasil perhitungan distribusi derajat pada simulasi 1

\begin{tabular}{cccc}
\hline Sel Ragi ke & $\begin{array}{c}\text { Distribusi } \\
\text { Derajat }\end{array}$ & Jarak & $\begin{array}{c}\text { Distribusi } \\
\text { Derajat }\end{array}$ \\
\hline 3 & 0.12 & 8 & 0.173228346 \\
1 & 0.11 & 9 & 0.118110236 \\
4 & 0.08 & 7 & 0.05511811 \\
9 & 0.07 & 15 & 0.047244094 \\
10 & 0.07 & 14 & 0.039370079 \\
12 & 0.07 & 11 & 0.039370079 \\
6 & 0.06 & 10 & 0.039370079 \\
7 & 0.06 & 17 & 0.031496063 \\
8 & 0.06 & 13 & 0.031496063 \\
5 & 0.04 & 16 & 0.023622047 \\
\hline
\end{tabular}

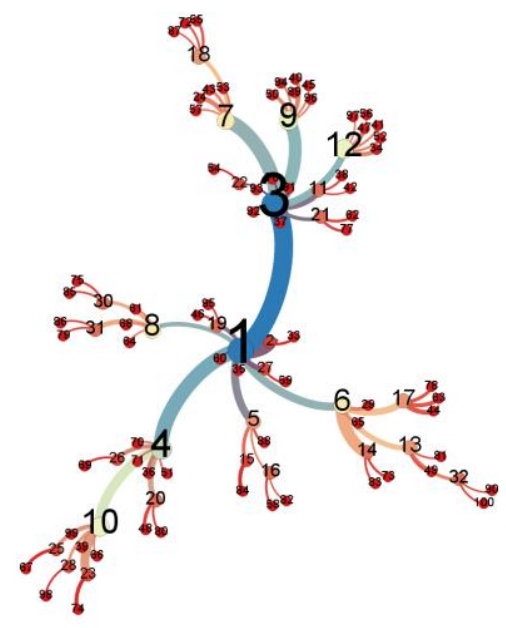

GAMBAR 5. Pemetaan Struktur pada Simulasi Pertama

Pada gambar di atas terlihat secara jelas sel ragi mana yang memiliki produktivitas paling tinggi. Sel ragi itu ditunjukkan oleh no. 3 dengan nilai distribusi derajat paling tinggi diantara yang lainnya. Sel ragi kedua yang produktif yaitu sel ragi pertama dan diikuti oleh sel ragi no 49 dan seterusnya. Jika merujuk pada hasil ini terlihat bahwa tidak terpadat pola khusus pada pembentukan sel ragi yang paling produktif. Karena tidak berdasarkan dari umur sel ragi itu sendiri.

Selanjutnya jarak disini bermakna jarak antara sel induk dengan sel anak yang terbentuk. Data merujuk pada kondisi akhir yaitu pada saat telah terbentuk 100 sel ragi secara sempurna. Pada pemetaan struktur terlihat bahwa penulis mengasumsikan jarak antara sel induk dan sel anak sebagai 
weight atau bobot dari jaringan. Semakin tebal dan garis nya berarti sel induk dan sel anak memiliki jarak yang cukup besar dan terpisah cukup jauh. Berdasarkan data distribusi derajat jarak antara sel induk dan sel anak, mereka cenderung berada pada jarak 8 dan diikuti oleh 9, 7 dan seterusnya. Berdasarkan data didapatkan bahwa jarak ini masih berada pada rentang yang sangat dekat bahkan lebih kecil dari pada diameter sel induk dan anak jika dijumlahkan. Rata-rata diameter jumlah dari sel induk anak pada simulasi pertama ini adalah 16.08 .

TABEL 2. Hasil perhitungan distribusi derajat pada simulasi ke50

\begin{tabular}{cccc}
\hline Sel Ragi ke & $\begin{array}{c}\text { Distribusi } \\
\text { Derajat }\end{array}$ & Jarak & $\begin{array}{c}\text { Distribusi } \\
\text { Derajat }\end{array}$ \\
\hline 1 & 0.1 & 8 & 0.192 \\
8 & 0.09 & 9 & 0.12 \\
2 & 0.08 & 7 & 0.072 \\
4 & 0.08 & 15 & 0.04 \\
6 & 0.08 & 14 & 0.04 \\
5 & 0.07 & 10 & 0.032 \\
18 & 0.06 & 11 & 0.032 \\
10 & 0.05 & 13 & 0.032 \\
11 & 0.05 & 16 & 0.024 \\
17 & 0.05 & 24 & 0.024 \\
\hline
\end{tabular}

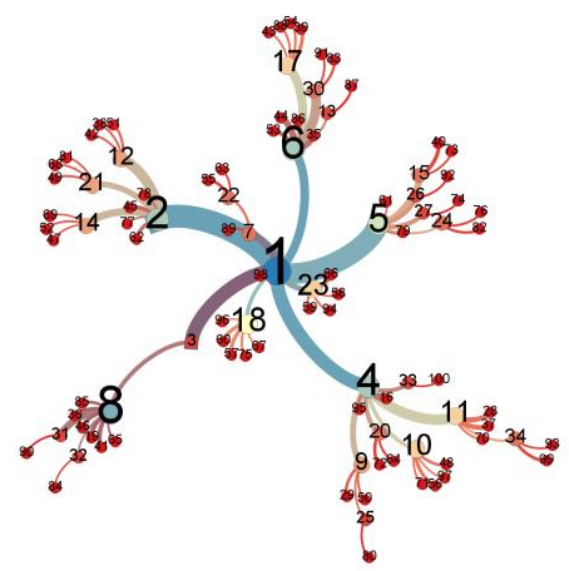

GAMBAR 6. Pemetaan Struktur pada Simulasi ke - 50

Pola yang hampir sama ditunjukkan pada simulasi ke-50. Pada simulasi ini produktivitas ragi juga ditunjukkan oleh ragi, tidak berdasarkan umur mereka. Akan tetapi produktivitas ini cenderung terbentuk secara acak. Dan untuk persebaran dari jarak antara sel induk dan sel anak terlihat pula bahwa sel induk dan sel anak cenderung berada pada jarak yang dekat yaitu pada jarak 8, 9 dan seterusnya. Jarak ini lebih kecil dari jumlah diameter sel induk dan sel anak pada simulasi ke-50 ini yaitu sebesar 16.10.

TABEL 3. Hasil perhitungan distribusi derajat pada simulasi ke-100

\begin{tabular}{cccc}
\hline Sel Ragi ke & $\begin{array}{c}\text { Distribusi } \\
\text { Derajat }\end{array}$ & Jarak & $\begin{array}{c}\text { Distribusi } \\
\text { Derajat }\end{array}$ \\
\hline 1 & 0.1 & 8 & 0.225806452 \\
7 & 0.08 & 9 & 0.096774194 \\
11 & 0.08 & 7 & 0.096774194 \\
2 & 0.07 & 15 & 0.048387097 \\
3 & 0.07 & 10 & 0.040322581 \\
12 & 0.07 & 14 & 0.032258065 \\
\hline
\end{tabular}




\begin{tabular}{cccc}
\hline 5 & 0.06 & 17 & 0.032258065 \\
18 & 0.06 & 13 & 0.032258065 \\
20 & 0.06 & 32 & 0.016129032 \\
4 & 0.05 & 46 & 0.016129032 \\
\hline
\end{tabular}

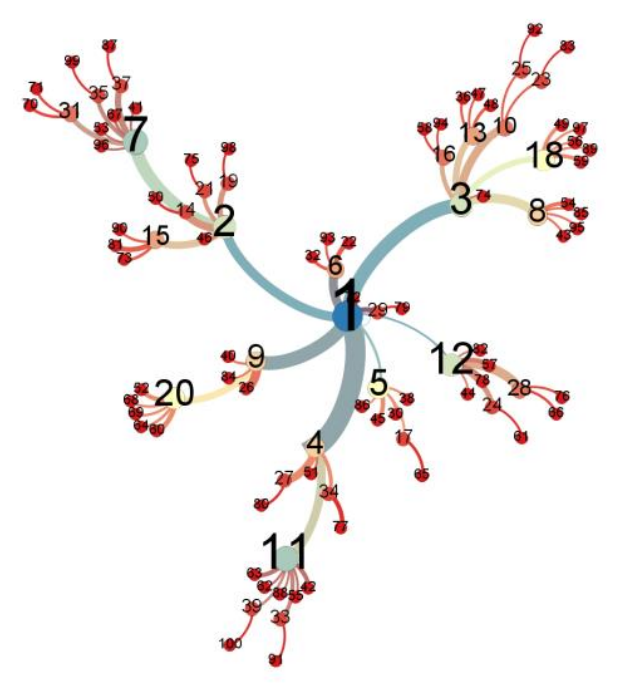

GAMBAR 7. Pemetaan Struktur pada Simulasi ke - 100

Simulasi ke-100 juga menunjukkan pola yang sama, sel ragi yang paling produktif yaitu sel ragi no. 1 dan selanjutnya diikuti oleh sel ragi no.7, 11 dan seterusnya. Pola produktivitas ragi ini tidak dipengaruhi oleh umur dari ragi tersebut.

Distribusi jarak antara sel induk dan sel anak paling banyak yaitu pada jarak 8, yang ditunjukkan oleh nilai distribusi derajat paling tinggi. Nilai rata-rata dari jumlah diamter sel induk dan sel anak pada simulasi ke-100 ini adalah 15.92. Pola ini hampir sama dengan simulasi sebelumnya. Dan apabila dipetakan dalam bentuk grafik maka didapatkan persebaran jarak dari sel induk dan sel anak adalah sebagai berikut:

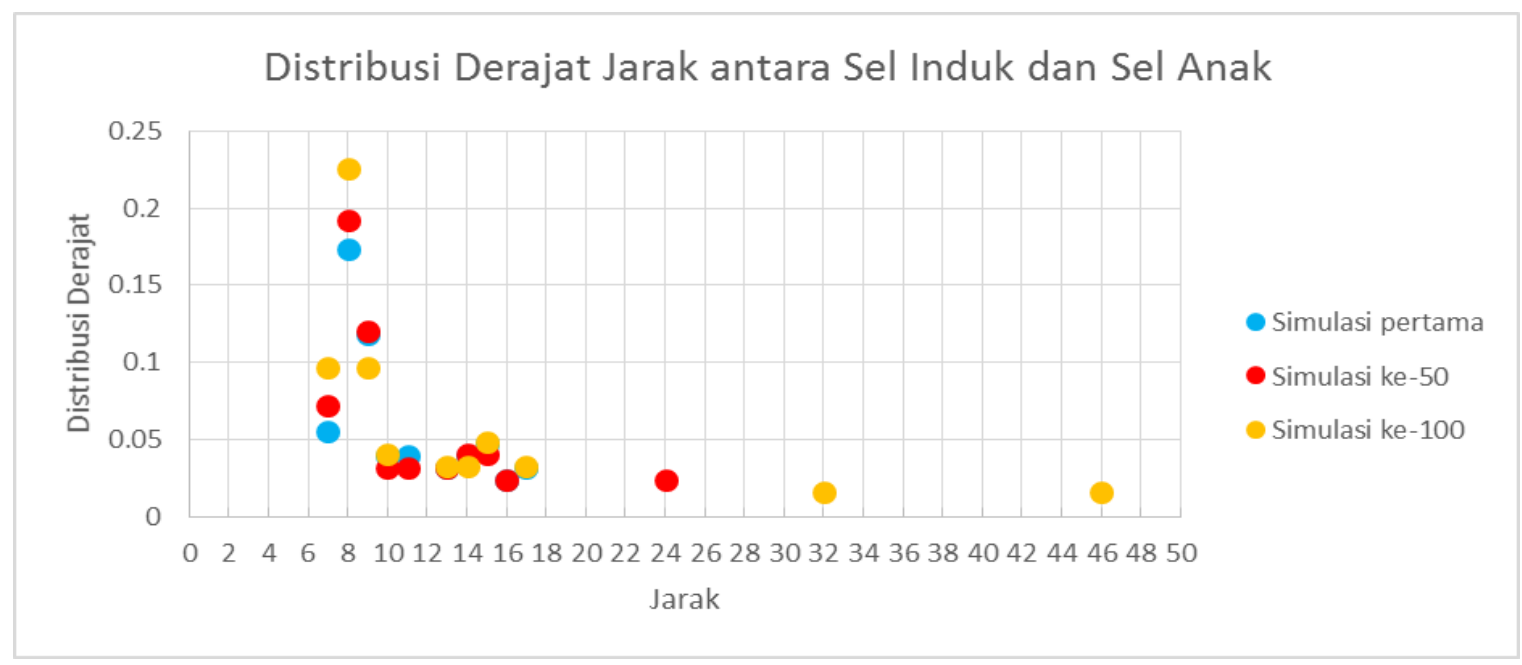

GAMBAR 8. Grafik persebaran distribusi derajat jarak sel induk dan sel anak

Berdasarkan grafik persebaran distribusi derajat terhadap jarak di atas terlihat jelas bahwa sel induk dan sel anak cenderung berada pada jarak yang lebih kecil dari jumlah diameter sel induk dan sel anak. Sel induk dan sel anak sering berada jarak $8-16$ dengan nilai rata-rata jumlah diameter sel 
16. Sel anak yang berada pada posisi ini dominan ditempati oleh sel anak generasi ketiga dan keempat atau sel anak yang baru terbentuk. Sel induk dan sel anak akan berada sangat dekat sebagai syarat utama terbentuknya sel anak, yaitu adanya interaksi langsung antara sel induk dan sel anak. Kemudian posisi sel anak yang lebih tua akan terus tergeser oleh sel anak baru yang terbentuk. Terlihat bahwa sel anak tertua memiliki jarak yang paling jauh dari sel induknya.

\section{KESIMPULAN}

Berdasarkan analisis network yang dilakukan pada sistem granular (perkembangbiakan koloni ragi) dapat disimpulkan bahwa produktivitas sel ragi tidak ditentukan oleh umur dari sel ragi tersebut. Produktivitas sel ragi terbentuk secara acak. Selain itu jarak antara sel induk dan sel anak berada pada jarak yang cukup dekat, hal ini merupakan syarat utama terbentuknya sel anak, yaitu adanya interaksi langsung (sentuhan) antara sel induk dan sel anak, yang kemudian jarak ini akan terus bertambah seiring dengan pembentukan sel anak yang baru. Sel anak tertua memiliki jarak yang paling jauh dari sel induknya.

\section{UCAPAN TERIMA KASIH}

Penulis mengucapkan terima kasih kepada berbagai pihak yang telah membantu dalam melakukan penelitian serta penulisan makalah ini.

\section{REFERENSI}

[1] D. Aprianti, S. N. Khotimah, S. Viridi, "Budding Yeast Colony Growth Study Based on Circular Granular Cell.” in 6th Asian Physics Symposium, Bandung. 2016, J.Phys.: Conf. Ser. 7390110012016.

[2] M. Newman, "Mixing Patterns in Networks." Physical Review E, 67, art.no-026126.2003

[3] M. Newman, "Mathematics of Network," in Networks : An Introduction. Oxford: Oxford University Press, 2010, ch. 6, pp. $101-105$.

[4] L. H. Hartwell, J.J. Hopfield, S. Leibler, A.W. Murray. "From molecular to modular cell biology." Nature, 402, 47.1999.

[5] U. Brandes, T. Erlebach, "Introduction," in Network Analysis: Methodological Foundation, Berlin: Springer, 2004, ch. 1, pp. 16 - 34. 